\title{
Prospects for Constructing Nano-Bio-Economics in Ukraine: Using Sensor Systems on The Basis of Nbic-Technologies for Medico-Environmental and Industrial Needs
}

\author{
Matyushenko Igor (Ph.D.) ${ }^{1}$, Moiseienko Yuri (Postgraduate) ${ }^{2}$, Khanova Elena (Ph.D.) ${ }^{3}$ \\ ${ }^{1}$ The Department of Foreign Economic Relations and Touristic Business, V.N. Karazin Kharkiv National \\ University, Ukraine \\ 2 Scientific research center for industrial development problems of National academy of sciences of Ukraine, \\ Ukraine
}

3 The Department of Foreign Economic Relations and Touristic Business, V.N. Karazin Kharkiv National niversity, Ukraine

\begin{abstract}
Convergence and integration of nano-bio-info-cogno-technologies considerably influence the capabilities of creating nano-bio-economics in any country and qualitatively change the directions of those technologies application. The article deals with the comprehensive research in the sphere of sensor systems using NBIC-technologies to solve medical-environmental problems, which was performed by National Academy of Science of Ukraine (NASU) during 2003-2013. The article demonstrates that in the course of implementing the comprehensive scientific-technical program "Sensor systems for medical-environmental and industrialtechnologic needs" in 2010-2012, a number of appliances for medical-environmental and industrial purposes was developed that undergo testing in real-life conditions. The article also presents the main prospective research directions in the sphere of creating sensor systems for medical-environmental and industrial-technologic needs in Ukraine till 2017, including also design of metrological support and research operation of working experimental appliances' samples ready for practical use to perform express analysis in bio-technology, medicine, ecology and when managing industrial technological processes.
\end{abstract}

Keywords: nano-bio-economics, sensor systems, NBIC-technologies, medical-environmental problems, appliances for express analysis

\section{INTRODUCTION}

In modern nano-bio-economics, production of sensor enginery exigent products goes in line with the $21^{\text {st }}$ century world scientific-technical trends, because it stipulates creation of new materials on the basis of high technologies, implementation of principally new sensor arrays on the broad base of physical effects, comprehensive utilization of information networks to optimize maximum number of production processes in industry, agriculture, in transport as well as to perform environmental monitoring. As of today, Ukraine faces many problems on the way of economic potential recovery and efficient industrial and agricultural production setting. One of the challenges in setting modern nano-bio-economics in Ukraine is to perform research of the capacities to develop national converging sensor structures for medico-environmental and industrial needs, which is the only possibility to avoid unwanted costs of products' adapting to world markets and to protect national consumers and goods producers. At the same time ever-growing implementation of NBIC-technologies in the developed countries' bio-economics requires review of the prospects for their implementation to solve medico-biological problems and environmental protection in Ukraine. The article aims at reviewing the nano-bio-economy development prospects in Ukraine on the grounds of designing and implementing sensor systems based on NBIC-technologies for medico-environmental and industrial needs.

\section{LITERATURE REVIEW}

The named problem was tackled by many renown scientists, including also M. Roco, W. Bainbridge, B. Tonn ,G. Whitesides [1;2], who studied the issues of knowledge, technologies and society convergence; L. Foster [3] worked with the issues of using nano-technologies for bioeconomy; A. Kazantsev, V. Kisilev, D. Rubvalter, O. Rudenskiy

\footnotetext{
${ }^{1}$ Corresponding Author: igormatyushenko@mail.ru
} 
[4], P. Maltsev [5], F. Rahman [6], together with Ukrainian scientists M. Kizim, I. Matyushenko, I. Buntov, O Khanova $[7 ; 8 ; 9 ; 10 ; 11 ; 12]$ et.al. dealt with the development and prospects for NBIC-civilization.

\section{DISCUSSION}

Convergence and integration of nano-bio-info-cogno-technologies provide for fantastic increase of bio-technologies capabilities at the expense of qualitative strengthening of their directedness and areas of application. Thanks to NBIC-technologies wide application the created cutting-edge sensor systems in comparison with the available analytical methods could ensure faster, more reliable, more sensitive and cheaper analysis of different substances. It would provide for preventing entry of polluted food products into trade network, environmental pollution, consumption of polluted with hazardous chemical compounds and infectious agents drinking water, improve quality and accessibility to medical diagnostics, control over technological processes in pharmaceutical, biotechnological and chemical production.

Research in the sphere of sensor systems and technologies to solve medico-environmental problems in Ukraine has rather a long history in Ukraine. For example, during 2003 - 2006 within the framework of the Comprehensive program in fundamental research of the National Academy of Science of Ukraine (NASU) "Research in the sphere of sensor systems and technologies" 46 scientific projects were under implementation attracting six departments of the NASU, specifically: departments of Chemistry, Molecular Biology, Biochemistry, Experimental and Clinical Physiology, Physics an d Astronomy, Energy Physics-Technical Problems, Informatics, Physics-Technical Problems of Materials Science [13].

NASU scientific-technical program "Sensor systems for medical-environmental and industrial-technological needs" is directed to implement sensors into practice, because in comparison with the current analytical methods they could ensure a faster, more reliable, more sensitive and cheaper analysis of different substances. It would provide for preventing entry of polluted food products into trade network, environmental pollution, consumption of polluted with hazardous chemical compounds and infectious agents drinking water, improve quality and accessibility to medical diagnostics, control over technological processes in pharmaceutical, biotechnological and chemical production.

Therefore, production of sensor enginery exigent products goes in line with the $21^{\text {st }}$ century world scientifictechnical trends, because it stipulates creation of new materials on the basis of high technologies, implementation of principally new sensor arrays on the broad base of physical effects, comprehensive utilization of information networks to optimize maximum number of production processes in industry, agriculture, in transport as well as to perform environmental monitoring. Ukraine, which has many problems on the way of economic potential recovery and efficient industrial and agricultural production setting, appears to have the only opportunity to avoid unwanted costs of products' adapting to world markets and protect own consumers and goods producers with the help of developing its national high technologies.

In the course of the program implementation in 2003-2006 a number of fundamental and technological problems were solved, including:

General regularities of the processes to form organized bio-molecular layers were established; the ways of optimum banding of bio-selective material with physical converters' surfaces were identified (NASU Institute of molecular biology and genetics, Biochemistry institute named after O.Palladin);

> In the result of electron and ion processes research in semi-conducting materials and structures there have been developed physical and physical-technical grounds to create sensors and sensor arrays on the basis of microelectronics materials (NASU Institute of semiconductors' physics named after V.Lashkaryov);

New basic electronic information-computing sensors' systems and optic-electronic appliances with computer processing were proposed (NASU Institute of electrodynamics, NASU Institute of cybernetics named after V.Glushkov);

Theoretic and technological grounds to create principally new selective elements on the basis of bio-mimics were developed, which is extremely important for further development of stable sensors capable to work in real-time mode and in rugged conditions (NASU Institute of molecular biology and genetics, NASU Institute of chemistry of high-molecular compounds); 
Physical-chemical grounds for creating sensitive layers from electro-conductive polymers and nano-composite materials for sensor and multi-sensor systems were developed (NASU Institute of physical chemistry named after L.Pisarzhevskiy);

New materials on the basis of coordinating compounds, meso-porous matrixes and composites to develop highsensitive sensors and intellectual sensor systems as well as high-selective synthetic receptors of cations, anions and neutral organic molecules, including also chiral and bio-active ones, on the basis of macro-cyclic compounds - calixarenes and cyclophanes were created (NASU Institute of organic chemistry, NASU Institute of general and non-organic chemistry named after V. Vernadskiy).

Close cooperation between experts in the fields of biology, chemistry and physics to solve fundamental problems is one of the major positive outcomes of the program.

NASU Presidium Resolution No.322, dated 09.12.2009, approved the Concept for comprehensive scientifictechnical program "Sensor systems for medical-environmental and industrial-technologic needs" for the period 2010 - 2012 [14]. In the result of the program implementation in 2010 - 2012 a number of appliances for medical-environmental and industrial-technologic needs were designed and manufactured and currently undergo testing in real-life conditions, as Table 1 presents [15].

Table1. Appliances for medical-environmental and industrial-technologic needs, developed by NASU institutions in 2010-2012

\begin{tabular}{|c|c|c|c|}
\hline $\begin{array}{c}\text { Area of } \\
\text { application }\end{array}$ & The most prominent result & Practical value & Global problem \\
\hline 1 & 2 & 3 & 4 \\
\hline \multirow{3}{*}{$\begin{array}{l}\text { Medical } \\
\text { diagnostics }\end{array}$} & $\begin{array}{l}\text { Experimental samples of } \\
\text { appliances on the basis of ion- } \\
\text { selective field-effect transistors } \\
\text { were created }\end{array}$ & $\begin{array}{l}\text { Simultaneous quantitative analysis of } \\
\text { glucose, blood urea nitrogen (BUN) } \\
\text { and creatinine in human blood and } \\
\text { blood dialysate in patients with renal } \\
\text { failure }\end{array}$ & $\begin{array}{l}\text { Habitancy } \\
\text { depopulation } \\
\text { and ageing }\end{array}$ \\
\hline & $\begin{array}{l}\text { Research sample of sensor } \\
\text { appliance was manufactured }\end{array}$ & $\begin{array}{ll}\text { Express-diagnostics } & \text { of } \\
\text { Helicobacteriosis at stomach ulcer } & \end{array}$ & $-\ll-$ \\
\hline & $\begin{array}{l}\text { Experimental samples of opto- } \\
\text { electronic bio-sensors on the } \\
\text { surface plasma resonance were } \\
\text { created }\end{array}$ & $\begin{array}{l}\text { Research of human blood } \\
\text { coagulability \& determi-ning separate } \\
\text { compo-nents of coagulability system }\end{array}$ & $-\ll-$ \\
\hline \multirow{3}{*}{$\begin{array}{l}\text { Environmental } \\
\text { monitoring of } \\
\text { industrial zones }\end{array}$} & $\begin{array}{l}\text { Experimental sample of hydrogen } \\
\text { optic sensor with remote } \\
\text { indication unit was manufactured }\end{array}$ & Industrial sites monitoring & $\begin{array}{l}\text { Environmental } \\
\text { pollution }\end{array}$ \\
\hline & $\begin{array}{l}\text { Experimental samples of enzyme } \\
\text { multi-bio-sensor on the basis of } \\
\text { pH-sensitive field-effect } \\
\text { transistors were created }\end{array}$ & $\begin{array}{l}\text { Determining general toxicity of waste } \\
\text { water and separate toxic substances in } \\
\text { compounds }\end{array}$ & $-\ll-$ \\
\hline & $\begin{array}{l}\text { Experimental sample of the } \\
\text { appliance on the basis of } \\
\text { electrochemical bio-sensors was } \\
\text { designed, manufactured and } \\
\text { adjusted }\end{array}$ & Determining phormaldegide content & $-\ll-$ \\
\hline \multirow{3}{*}{$\begin{array}{l}\text { Food- } \\
\text { processing } \\
\text { industry and } \\
\text { agriculture }\end{array}$} & $\begin{array}{l}\text { Experimental sample of 4-channel } \\
\text { conductometric measuring multi- } \\
\text { bio-sensor system was designed } \\
\text { and manufactured }\end{array}$ & Determining saccharides in foodstuff & Lack of food \\
\hline & $\begin{array}{l}\text { Small batch of portable chrono- } \\
\text { fluoro-meters "Floratest" was } \\
\text { manufactured }\end{array}$ & $\begin{array}{l}\text { Determining plants' functional } \\
\text { conditions }\end{array}$ & $-\ll-$ \\
\hline & $\begin{array}{l}\text { Portable appliance on the basis of } \\
\text { pH-sensitive field-effect } \\
\text { transistors was created }\end{array}$ & $\begin{array}{l}\text { Determining toxic glycoalkaloids in } \\
\text { potatoes and foodstuff }\end{array}$ & $-\ll-$ \\
\hline
\end{tabular}




\begin{tabular}{|c|c|c|c|}
\hline & $\begin{array}{l}\text { Experimental sample of 4-channel } \\
\text { amperometric measuring system } \\
\text { was designed and manufactured }\end{array}$ & $\begin{array}{l}\text { Wine and wine materials quality } \\
\text { analysis for wine-making }\end{array}$ & $-\ll-$ \\
\hline & $\begin{array}{l}\text { Experimental sample of 8-channel } \\
\text { gas-analyzing sensor system of } \\
\text { «electronic nose» type on the basis } \\
\text { of quartz micro-balance and } \\
\text { calixarenes was designed and } \\
\text { manufactured }\end{array}$ & $\begin{array}{l}\text { Detecting gas mixtures components by } \\
\text { chemical images }\end{array}$ & $-\ll-$ \\
\hline & $\begin{array}{l}\text { Algorithm-setting and adjustment } \\
\text { of hardware-software means to } \\
\text { certify primary pH-PT-electrodes } \\
\text { optimized with the help of the } \\
\text { measuring converter and portable } \\
\text { automated characterograph }\end{array}$ & $\begin{array}{l}\text { Certification of primary pH-PT- } \\
\text { electrodes }\end{array}$ & $\begin{array}{l}\text { Technologic } \\
\text { inferiority; } 6^{\text {th }} \\
\text { technology } \\
\text { revolution }\end{array}$ \\
\hline & $\begin{array}{l}\text { Reference measures for } \\
\text { metrological certification of } \\
\text { electronic measuring channel of } \\
\text { conductometer and amper-metric } \\
\text { devices were developed; its } \\
\text { sensitivity and errors due to } \\
\text { changes in sensors electric } \\
\text { parameters were researched }\end{array}$ & $\begin{array}{l}\text { Metrological certification of electronic } \\
\text { measuring channel of conductometer } \\
\text { and amper-metric devices }\end{array}$ & $-\ll-$ \\
\hline $\begin{array}{l}\text { Metrologic } \\
\text { support for } \\
\text { created } \\
\text { appliances }\end{array}$ & $\begin{array}{l}\text { Methods to prepare calibrating } \\
\text { compounds of phormaldegide, } \\
\text { mercury (II) nitrite, trichlorphone } \\
\text { glucose sucrose, lactose, maltose, } \\
\text { butirylholinchloride, } \alpha \text {-chaconine } \\
\text { and } \alpha \text {-salonine, urea, creatinine, } \\
\text { ethanol, glycerin, lactate, phenol, } \\
\text { catechol were created jointly with } \\
\text { the branch «Ukrmetrteststandard» }\end{array}$ & $\begin{array}{l}\text { Methods to prepare calibrating } \\
\text { compounds }\end{array}$ & $-\ll-$ \\
\hline & $\begin{array}{l}\text { Methods to calibrate laboratory } \\
\text { prototypes of devices to measure } \\
\text { mole concentration of steroid } \\
\text { glyco-alkaloids in potatoes; } \\
\text { glucose and sucrose concentration } \\
\text { in juices; o-hydroxiphenoles and } \\
\text { trichlorophone concentration in } \\
\text { river water; urea, glucose and } \\
\text { creatinine concentration in blood } \\
\text { serum, in pharmaceutical drugs } \\
\text { and detergents, were created }\end{array}$ & $\begin{array}{l}\text { Measuring concentration of hazardous } \\
\text { and other substances in foodstuff, } \\
\text { water, blood, pharmaceutical drugs } \\
\text { and detergents. }\end{array}$ & $-\ll-$ \\
\hline & $\begin{array}{lr}\text { First stages to register } & \text { sensor } \\
\text { device "Helicotester" as a medical } \\
\text { purpose appliance } & \text { were } \\
\text { accomplished } & \end{array}$ & $\begin{array}{l}\text { Appliance for noninvasive } \\
\text { diagnostics oxpress- } \\
\text { helicobacteriosis. }\end{array}$ & $-\ll-$ \\
\hline
\end{tabular}

\section{Compsed by [15]}

Moreover, NASU Presidium Resolution No.242, dated 29.11.2012, approved the Concept of the comprehensive scientific-technical program "Sensor appliances for medical-environmental and industrial-technologic needs: metrological support and research operation" for the period $2013-2017$ [16]. The main aim of the Program for the period 2013-2017 is to develop metrological support and perform research operation of devices' working experimental samples, ready to be practically used for express analysis in biotechnology, medicine, ecology and 
when managing technological processes in industry. The most prominent results of implementing scientific projects within the framework of this program in 2013 are presented in Table 2 [17].

Table2. The most prominent results of implementing Comprehensive Scientific-technical Program "Sensor appliances for medical-environmental and industrial-technologic needs: metrological support and research operation" for the period 2013

\begin{tabular}{|c|c|c|c|c|c|}
\hline Year & $\begin{array}{l}\text { Program } \\
\text { direction }\end{array}$ & Most prominent result & Practical value & Branch & $\begin{array}{l}\text { Global } \\
\text { problem }\end{array}$ \\
\hline \multirow{6}{*}{2013} & \multirow{5}{*}{$\begin{array}{l}\text { Medical } \\
\text { diagnostics }\end{array}$} & $\begin{array}{l}\text { Clinical testing of the medical } \\
\text { appliance "Device for express- } \\
\text { diagnostics of stomach } \\
\text { helicobacteriosis «Helicotester» } \\
\text { was successfully clinically tested }\end{array}$ & $\begin{array}{l}\text { Device to diagnose } \\
\text { sto-mach helico- } \\
\text { bacteriosis }\end{array}$ & Medicine & $\begin{array}{l}\text { Habitancy } \\
\text { depopulation } \\
\text { and ageing }\end{array}$ \\
\hline & & $\begin{array}{l}\text { A batch of } 3 \text { experimental } \\
\text { samples of conductive-metric } \\
\text { bio-sensor systems were } \\
\text { manufactured, for which the } \\
\text { corresponding } \\
\text { documentation was developed. } \\
\text { Metrological research of bio- } \\
\text { sensor to determine maltose } \\
\text { concentration was performed. }\end{array}$ & $\begin{array}{l}\text { Conductive-metric } \\
\text { bio-sensor systems }\end{array}$ & $-\ll-$ & $-\ll-$ \\
\hline & & $\begin{array}{l}\text { Two working samples of the } \\
\text { modified version of the secondary } \\
\text { measuring converter for } \\
\text { differential pH-PT-electrodes } \\
\text { with built-in modules for } \\
\text { diagnostics, control and } \\
\text { indication were manufactured and } \\
\text { adjusted. Laboratory prototype of } \\
\text { biosensor to determine arginine } \\
\text { on the basis of reverse inhibition } \\
\text { of the urea enzyme effect was } \\
\text { designed. }\end{array}$ & $\begin{array}{l}\text { Prototype of } \\
\text { biosensor to } \\
\text { determine arginine }\end{array}$ & $-\ll-$ & $-\ll-$ \\
\hline & & $\begin{array}{l}\text { Experimental samples of devices } \\
\text { for amper-metric biosensors were } \\
\text { manufactured. Protocols of } \\
\text { lactate, ethanol and glucose } \\
\text { measurements in real samples by } \\
\text { the earlier developed } \\
\text { methodology were developed. }\end{array}$ & $\begin{array}{l}\text { Amper-metric } \\
\text { biosensors }\end{array}$ & $-\ll-$ & $-\ll-$ \\
\hline & & $\begin{array}{l}\text { On the basis of purified agents of } \\
\text { flavo-cytro-chromium b2 and } \\
\text { gold nano-particles, a laboratory } \\
\text { prototype of electric-chemical } \\
\text { enzyme mediator-free biosensor } \\
\text { of «third generation» type was } \\
\text { constructed }\end{array}$ & $\begin{array}{l}\text { Biosensors for } \\
\text { quantitative } \\
\text { estimation of L- } \\
\text { lactate content }\end{array}$ & $-\ll-$ & $-\ll-$ \\
\hline & Environmental & Portable biosensor devices to & Biosensors & Environm & Environmental \\
\hline
\end{tabular}




\begin{tabular}{|c|c|c|c|c|}
\hline \multirow[t]{5}{*}{$\begin{array}{l}\text { monitoring of } \\
\text { industrial zones }\end{array}$} & $\begin{array}{l}\text { determine } 0 \text {-hydroxiphenoles } \\
\text { content was created and } \\
\text { experimental check of the } \\
\text { developed sensor systems to } \\
\text { monitor environment was carried } \\
\text { out }\end{array}$ & $\begin{array}{l}\text { einvomental } \\
\text { monitoring }\end{array}$ & $\begin{array}{c}\text { ental } \\
\text { protection }\end{array}$ & pollution \\
\hline & $\begin{array}{l}\text { Methodology to calibrate } \\
\text { laboratory prototype of sensor } \\
\text { device on the basis of polymers- } \\
\text { biomimetrics with tyrosinase } \\
\text { activity was developed. } \\
\text { Comparison between biosensor } \\
\text { analysis data and traditional } \\
\text { instrumental analysis results was } \\
\text { carried out }\end{array}$ & $\begin{array}{l}\text { Methodology to } \\
\text { determine } 0- \\
\text { hydroxi-phenoles } \\
\text { content in waste } \\
\text { water }\end{array}$ & $-\ll-$ & $-\ll-$ \\
\hline & $\begin{array}{l}\text { New dummy of sensor system of } \\
\text { "electronic nose" type with } \\
\text { optimized parameters was } \\
\text { constructed; it provided for } \\
\text { improving ratio signal/noise and } \\
\text { for considerable decrease of } \\
\text { «operator factor» impact }\end{array}$ & $\begin{array}{l}\text { Dummy of sensor } \\
\text { system of } \\
\text { "electronic nose" }\end{array}$ & $-\ll-$ & $-\ll-$ \\
\hline & $\begin{array}{l}\text { Two arrays of sensor elements to } \\
\text { detect aromatic compounds and } \\
\text { ketones were created }\end{array}$ & $\begin{array}{l}\text { Sensors to detect } \\
\text { aroma-tic } \\
\text { compounds and } \\
\text { ketones }\end{array}$ & $-\ll-$ & $-\ll-$ \\
\hline & $\begin{array}{l}\text { Procedures to measure some } \\
\text { heavy metals content in water } \\
\text { samples with the help of bio- } \\
\text { selective elements on the basis of } \\
\text { urea enzyme and acetylcholine } \\
\text { and general toxicity were } \\
\text { developed }\end{array}$ & $\begin{array}{lr}\text { Procedures } & \text { to } \\
\text { measure } & \text { some } \\
\text { heavy } & \text { metals } \\
\text { content } & \end{array}$ & $-\ll-$ & $-\ll-$ \\
\hline $\begin{array}{l}\text { Food- } \\
\text { processing } \\
\text { industry and } \\
\text { agriculture }\end{array}$ & $\begin{array}{l}\text { In field conditions it was } \\
\text { demonstrated the capability of } \\
\text { using developed bio-sensor bio- } \\
\text { luminescent and static capacitors } \\
\text { bank analyzers for express- } \\
\text { monitoring of agricultural land } \\
\text { condition and fodder quality, feed } \\
\text { additives and agricultural } \\
\text { products by the indicators of } \\
\text { pollution with organic and } \\
\text { nonorganic pollutants }\end{array}$ & $\begin{array}{l}\text { Using bio-sensor } \\
\text { analy-zers to moni- } \\
\text { tor soil condition, } \\
\text { quality of fodder, } \\
\text { feed additives and } \\
\text { agricultural } \\
\text { products }\end{array}$ & $\begin{array}{c}\text { Agricultur } \\
\mathrm{e}\end{array}$ & Lack of food \\
\hline
\end{tabular}

Composed by [17]

\section{CONCLUSION}

Comprehensive scientific-technical programs of the National Academy of Science of Ukraine in creating sensor appliances for medical-environmental and industrial needs are aimed at developing and implementing new sensor 


\section{American Research Journal of Business and Management, Volume 1, Issue 2, 2015 ISSN 2379-1047}

systems in practice. Such appliances could ensure a faster, more reliable, more sensitive and cheaper analysis of different substances if comparing with the available analytical methods.

Development and utilization of the mentioned sensor devices would provide for: increasing quality and accessibility of medical diagnostics; preventing environmental pollution; preventing polluted foodstuff entry into trade network; preventing polluted with hazardous chemical compounds and infectious agents drinking water consumption by the population; improving control over technological processes of pharmaceutical, bio-technological and chemical industries.

\section{REFERENCES}

[1] Roco, M., Bainbridge, W., Tonn, B., Whitesides, G., eds. (2013). Converging knowledge, technology and societyBeyond convergence of nano-bio-info-cognitive technologies. Dordrecht, Heidelberg, New York, London.

[2] Roco, M., Bainbridge, W., eds. (2006). Managing Nano-Bio-Info-Cogno Innovations. Converging Technologies in Society. Heidelberg; New York.

[3] Foster, L. (2006). Nanotechnology: Science, Innovation and Opportunity. New York.

[4] Kazantsev, A., Kisilev, V., Rubvalter, D. \& Rudenskiy, O. (2012). NBIC-technologies: Innovative civilization of the XXI century. Moscow.

[5] Maltsev, P. (2008). Nanotechnology. Nanomaterials. Nano-system hardware. World achievements. Moscow.

[6] Rahman, F. (2010). Nanostructures in electronics and photonics. Moscow.

[7] Kyzym, M. \& Matyushenko, I. (2011). Prospects for nanotechnologies development and commercialization in world countries and in Ukraine. Kharkiv.

[8] Matyushenko, I. \& Buntov, I. (2012). Prospects for NBIC-technologies convergence to create a technological platform for new economy. Business inform, 409(2): 66-71.

[9] Matyushenko, I. \& Buntov, I. (2011). The synergetic effect of development of NBIC-technologies for solution of global human problems. The Problems of Economy, 4: 3-13.

[10] Matyushenko, I. \& Khanova, O. (2014). Convergence of Nbic-Technologies as a Key Factor in the Sixth Technological Order' Development of the World Economy. Social Educational Project of Improving Knowledge in Economics. Journal L'Association 1901 «SEPIKE». Ausgabe 6. Osthofen, Deutschland, Poitiers, France, Los Angles, USA: 118-123.

[11] Matyushenko, I. \& Moiseenko, Yu. (2015). Outlook on bioeconomy development in Ukraine: introduction of molecular and cell biotechnologies in 2010-2013. International Journal of Economics, Commerce and Management. United Kingdom, Rochester, Vol. III (issue 5, May): 764-772. Retrieved on May 30, 2015 http://ijecm.co.uk/wpcontent/uploads/2015/05/3545.pdf.

[12] Matyushenko, I. \& Khaustova, V. (2015). Modern trands on bioeconomy development in the world: the introduction of NBIC-technologies in biomedicine. Integrated Journal of British, Navi Mumbai, India, Vol. 2 (issue 2, MAR-APR 2015): 103-118. Retrieved on May 30, 2015 http://www.ijbritish.com/Downloads.aspx?PA=IJBRITISH-279-PA.pdf.

[13] NASU Presidium Resolution № 23. (2007). Retrieved on January 31 , 2007 http://www1.nas.gov.ua/infrastructures/Legaltexts/nas/2007/regulations/Pages/23.aspx.

[14] NASU Presidium Resolution № 322. (2009). Retrieved on December 09, 2009 http://www1.nas.gov.ua/infrastructures/Legaltexts/nas/2009/regulations/OpenDocs/091209_322_conception.pdf.

[15] Presidium Resolution № 242. (2012). Retrieved on November 29, 2012 http://www1.nas.gov.ua/infrastructures/Legaltexts/nas/2012/regulations/OpenDocs/121129_242.pdf.

[16] NASU Presidium Resolution № 242. (2012). Retrieved on November 29, 2012 http://www1.nas.gov.ua /infrastructures/Legaltexts/nas/2012/regulations/OpenDocs/121129_242_d2.pdf.

[17] Progress report of the National Academy of Science of Ukraine for 2013. (2014). Kyiv, Ukraine: 1-564. 